\title{
Micro RNA as a Potential Biomarker for the Diagnosis of Neonatal Sepsis - A Review
}

\author{
Vidhya Ravi ${ }^{1}$, Kathir Subramanian², Jayanthi Sivasubramaniam³, \\ Danis Vijay Devaraj ${ }^{4}$, Sujhithra Appan Ramanujam ${ }^{5}$
}

\begin{abstract}
1, 4 Department of Microbiology, Chettinad Hospital and Research Institute (CHRI), Chettinad Academy of Research and Education, Kelambakkam, Tamilnadu, India. ${ }^{2}$ Department of Paediatrics, Chettinad Hospital and Research Institute (CHRI), Chettinad Academy of Research and Education, Kelambakkam, Tamilnadu, India. ${ }^{3}$ Department of Microbiology, Panimalar Medical College Hospital and Research Institute, Varadhrajapuram, Tamilnadu, India. ${ }^{5}$ Department of Allied Health Sciences, Chettinad Hospital and Research Institute (CHRI), Chettinad Academy of Research and Education, Kelambakkam, Tamilnadu, India.
\end{abstract}

\section{ABSTRACT}

Neonatal sepsis (NS) represents a significant threat around the globe. It is mostly a bacterial infection that occurs within 28 days of age. It is a serious condition which is induced by an infection and accompanied by characteristic inflammatory response. Unfortunately, detection of sepsis is challenging at its initial stages as signs and symptoms are non-specific, and the outcomes of gold standard blood culture are usually delayed with decreased sensitivity. The high mortality rate is intrinsically linked with time-consuming and non-reliable diagnostic techniques with lowsensitivity and specificity. This requires novel diagnostic biomarkers to overcome the limitations. Huge efforts have been made to identify new biomarkers of sepsis. Current scientific investigations have shown the role of latest sepsis biomarkers including circulating micro RNAs (miRNA). miRNAs are single stranded non-coding RNA molecules. They can regulate gene expression and can govern up to $60 \%$ of all protein coding genes. As a regulator, microRNAs can play a significant role in various biological mechanisms. During different pathological conditions, the distribution of circulating miRNAs can be altered. Research has demonstrated that the dysregulated miRNAs expression is associated with the pathogenesis of neonatal sepsis and may be critical for host immunity against infections. Some of the miRNAs were closely linked with the stage of the disease, and its prognosis. MicroRNAs are characterized by very high stability, specificity, and selectiveness. A wide range of miRNAs in the blood may be studied by using molecular techniques. Their diagnostic and prognostic values are high. They can be valuable biomarkers for diagnosis and may be useful in clinical decision-making. In this review, we summarize existing studies highlighting the role of circulating miRNAs in neonatal sepsis diagnosis. Mechanism of various micro RNAs like miRNA-181a, miRNA-146a, miRNA187, miRNA101 are described and its association with severity of neonatal sepsis will help in understanding the disease progression. miRNA dysregulation during gram-positive and gram-negative sepsis provides knowledge about pathogenesis. The regulation of immune response genes shows the association of miRNA with different immunological components. Forest plot analysis and comparison of various studies based on their regulation, sensitivity, specificity, p-value and AUC might be useful in critically analysing the different miRNA as a prognostic and diagnostic marker. There may be variations in diagnostic outcomes of miRNA which must be standardised before including it in routine laboratory testing. Combination of micro-RNA along with other biomarkers can be more promising in the diagnosis and prognosis of neonatal sepsis.
Corresponding Author:

Dr. Jayanthi Sivasubramaniam, Professor, Department of Microbiology, Panimalar Medical College Hospital and Research Institute, Varadhrajapuram, Poonamallee, Tamilnadu, India

E-mail: jayanthitanmicro@gmail.com

DOI: $10.14260 /$ jemds/2021/83

How to Cite This Article:

Ravi V, Subramanian K, Sivasubramaniam J et al. Micro RNA as a potential biomarker for the diagnosis of neonatal sepsis - a review. I Evolution Med Dent Sci 2021;10(06):375-380, DOI: 10.14260/jemds/2021/83

Submission 15-09-2020,

Peer Review 19-11-2020,

Acceptance 26-11-2020,

Published 08-02-2021.

Copyright (C) 2021 Vidhya Ravi et al. This is an open access article distributed under Creative Commons Attribution License [Attribution 4.0 International (CC BY 4.0)]

\section{KEY WORDS}

Neonatal Sepsis, Biomarkers, Circulating Micro RNA, Diagnosis 


\section{BACKGROUND}

Neonatal sepsis (NS), mostly a bacterial infection occurs within 28 days of age. Every year about 1 million infants worldwide die from NS, which poses a public health burden. ${ }^{1}$ It is a serious condition which is induced by an infection and accompanied by characteristic inflammatory response. Mostly among preterm infants it has significant morbidity and mortality, which can be related to inadequate potential diagnostic methods and delayed antibiotic treatment. ${ }^{2}$ Unfortunately, detection of sepsis is challenging at its initial stages as signs and symptoms are non-specific, and the outcomes of gold standard blood culture are usually delayed with decreased sensitivity. ${ }^{3}$

The National Institutes of Health defines a biomarker as a "characteristic that can be objectively measured and evaluated as an indicator of normal biological processes, pathological processes, or pharmacological responses to a therapeutic intervention". Biomarkers such as PCT (procalcitonin) and CRP (C-Reactive Protein) are commonly used in sepsis diagnosis but are of limited sensitivity and specificity. ${ }^{4}$ This requires novel diagnostic biomarkers to overcome the limitations. Huge efforts have been made to identify new biomarkers of sepsis such as circulating micro RNAs. ${ }^{5}$

\section{MICRO RNA AS BIOMARKERS}

Micro RNAs (miRNAs) are single-stranded non coding RNA molecules. They are endogenous and small with length of 1824 nucleotides. They can regulate a gene expression by attaching to the target messenger RNAs (mRNAs) at their 3' untranslated region ( $3^{\prime} \mathrm{UTR}$ ). It is done by direct degradation of messenger RNA (mRNA) or translation inhibition. It can also inhibit protein synthesis at the post-transcriptional level. ${ }^{6}$

In humans over 1800 miRNAs have been characterized. These miRNA genes are estimated to represent about $1 \%$ of the human genome, but can govern up to $60 \%$ of all protein coding genes. Thus, one miRNA can affect numerous transcriptions. As a regulator, microRNAs can play a significant component in biological mechanisms, like cell proliferation and cell cycle. They are also progressing as modern immune response regulators which includes immune cell differentiation, function and development. ${ }^{7}$

Under various pathological and physiological conditions, the circulating microRNAs are expressed differently. Similarly, further research has demonstrated the dysregulated miRNAs expression is associated with the pathogenesis of neonatal sepsis and may be critical for host immunity against infections. Some of the miRNAs were closely linked with the stage of the disease, and its prognosis. ${ }^{8}$

Micro RNAs are characterized by very high stability (increased or decreased temperature, changes in $\mathrm{pH}$, and repetitive cycles of freezing and thawing), specificity, and selectiveness. ${ }^{6} \mathrm{~A}$ wide range of miRNAs in the blood may be studied by using molecular techniques (array and single polymerase chain reaction-based methods). Their diagnostic and prognostic values are high. They can be valuable biomarkers for diagnosis and may be useful in clinical decision-making. ${ }^{7}$

\section{Role of Various Micro RNA in Neonatal Sepsis Mi R-181a}

The serum expression of miR181a in NS patients is downregulated. Over-expression of miR181a in monocytes has been able to enhance the inflammatory reaction induced by Lipo-Poly-Saccharide (LPS) by targeting Toll Like Receptor (TLR) 4, which may further uncover the pathological mechanisms in the development of NS. TLR 4 binds to LPS of Gram-negative bacteria as a mechanism of innate immunity. Stimulation of LPS in monocytes also led to reduced miR181a expression. TLR4 has been demonstrated to be a specific target gene of miR181a. The upregulated levels of Tumour Necrosis Factor-TNF $\alpha$ and Inter-Leukin 8 (IL 8) induced by LPS -induced inflammation have been shown to be reduced by miR181a overexpression. TNF- $\alpha$ is a principal mediator of inflammatory response and IL 8 induces chemotaxis in target cells. MiR181a overexpression inhibits the inflammatory response induced by LPS, by targeting TLR4 at least partially. ${ }^{7}$

\section{Mi RNA-146-a}

In sepsis group, levels of serum miRNA-146-a were significantly reduced. It is associated with severity of neonatal sepsis. Lowest level was seen in paediatric septic shock group. miRNA-146-a level below 0.4 is correlated with increased rate of mortality. Procalcitonin, CRP, TNF- $\alpha$ and IL6 which induces acute phase response were negatively correlated with serum miRNA-146-a expression. ${ }^{8}$ Toll-like receptor 4 (TLR4) was found to be negatively regulated by miRNA-146 family (miR$146 \mathrm{a} / \mathrm{b}$ ). In neonatal monocytes, the increased level of miR146a expression following LPS stimulation may be a negative regulator of TRL4 activation. ${ }^{9}$

\section{Mi R-187 and mi R-101}

Expression of miR-187 and miR-101 were higher in neonatal sepsis in comparison with control group. miR-101 could serve as an optimistic biomarker for diagnosis of neonatal sepsis because it had statistical significance 10

\section{Mi R-21}

MiR-21 values were considerably increased in non-survivors when compared to survivors' group. Survival analysis showed higher levels of miR-21 expression were correlated with low rates of survival. In addition, miR-21 became a reliable predictor of sepsis prognosis particularly in combination with Score for Neonatal Acute Physiology (SNAP) II. ${ }^{10}$

\section{Mi R-223 and mi R-132}

In early onset sepsis, levels of miR-223 and miR-132 were decreased. It is related with higher levels of immunological genes involved in TLR signalling and may cause inflammatory changes. ${ }^{6}$

\section{Mi R - 25}

Mi R-25 expression in septic neonates was considerably upregulated and target gene of miR-25 was CD69. CD69 activates of $\mathrm{T}$ lymphocytes and natural killer cells. In sepsis patients, CD69 position ratio and CD69 protein level along with messenger RNA was higher. The possibility of sepsis in new-borns is related with miR-25-single-nucleotide polymorphism (SNP; rs41274221). ${ }^{11}$

Mi R-300 
Mi R-300 levels were overexpressed in septic neonate mouse model. It was related to inflammatory response such as increased autophagy, increased cell cycle and decreased apoptosis in endothelial cells. Thus, it denotes that miR-300 triggers sepsis and can act as therapeutic target.12

\section{Mi $R-23 b$}

Mi R-23b levels in new-borns who died from both early and late onset of sepsis was decreased significantly. The decrease in levels of miR-23b may be a key element which favours sepsis progression. ${ }^{13}$

mi $R-142 a-5 p$

In a model of zebra fish, infection with Staphylococcus epidermidis induces extreme down-regulation of dre-miR$142 a-5 p$, allowing for up-regulation of the IL- 6 signalling pathways. ${ }^{14}$

\section{Mi R-125b}

Higher levels of TNF- $\alpha$ are synthesised by neonatal monocytes. miR-125b significantly decreased following LPS stimulation in correlation with higher TNF- $\alpha$ expression. Precursor miR$125 \mathrm{~b}$ transfection into neonatal monocytes substantially reduced the expression of TNF- $\alpha$. This indicates miR-125b regulates TNF- $\alpha$ expression negatively. Proinflammatory reactions can be controlled by miR-125b modulation. ${ }^{15}$

\section{Mi RNA-26a}

The expression of miRNA-26a was decreased in neonatal sepsis while the levels of mRNA and IL- 6 were significantly increased. Direct target of miRNA-26a was found to be IL-6. Pathogenesis, disease progression and immune responses can be modulated by miRNA-26a ${ }^{16}$

\section{Mi R-15a and mi R-16}

In neonatal sepsis, the levels of miRNAs $15 \mathrm{a}$ and 16 are upregulated. The primary target of miR-15a / 16, was TLR 4, IRAK1 (Interleukin 1 Receptor-Associated Kinase 1 is responsible for adaptive immune response and inflammation). It suppresses the expression of TLR 4 and IRAK1. ${ }^{17}$

\section{Mi Rs-182 and 185}

Mi Rs-182 and 185 levels was found to be downregulated in neonatal sepsis. It was correlated with upregulation of apoptosis or programmed cell death inducing FAS-associated protein with death domain (FADD) gene expression. ${ }^{18}$

\section{Mi RNA 16 and miRNA 34a}

In the blood culture positive neonatal sepsis patients, levels of miRNA 16 was significantly increased when compared with negative blood culture and control groups. Mi RNA 34a levels were significantly decreased in blood culture positive group. We can propose that the levels of miRNA 16 are higher and the levels of miRNA34a are lower during neonatal infection. ${ }^{19}$

\section{Mi R-142-3p and let- $7 g$}

The lower levels of miR-142-3p and let-7 $g$ expression after LPS stimulation in neonatal Poly Morpho Nuclear (PMN) cells leads to increased synthesis of IL-6. PMN acts as phagocytes of innate immunity. ${ }^{20}$

\section{Mi R-181a and mi R-184}

In neonatal CD $4+\mathrm{T}$ cells, improved calcium signalling is induced by elevated amounts of miR-181a. Elevated levels of miR-184 and miR-181a led to reduced Nuclear Factor of Activated $\mathrm{T}$ cells1 (NFAT1) protein and decreased T Helper cells 1 (Th1) response which influences cell-mediated response and the production of various cytokines. This modified immune response is related to both miR-181a and $\operatorname{miR}-184 .{ }^{21}$

\section{MiR-155 and MiR-146a}

Upon TLR stimulation, neonatal Plasmacytoid Dendritic Cell (pDC) releases decreased amounts of Interferon- $\alpha$ (IFN- $\alpha$ has antiviral activity). In neonatal pDCs, increased amount of miR155 and miR-146a are found. They modulate the TLRdependent inflammatory responses by negative regulation and decrease the IFN- $\alpha$ synthesis. ${ }^{22}$

\section{MiR-181b}

Altered class-switch recombination of Immunoglobulin-IgM to IgG / IgA in neonatal B cells was linked to the higher levels of miR-181 b. Such results highlighted the role of miRNAs in neonatal humoral immunity programming. ${ }^{23}$

\section{MiR-29}

Neonatal CD8 + T cells have reduced miR-29 (miR-29a-3p miR-29 b-3p, and miR-29c-3p) expression until stimulation. Transcription factors like Eomes and Tbx21are the direct target of miR-29. This indicates the effective activation of neonatal naïve $\mathrm{CD} 8+\mathrm{T}$ cells which produces effector cytokines. ${ }^{24}$

\section{Let-7}

Over-expression of Let-7 has been found to reduces the synthesis of cytokines and interleukins (IL-10 and IL-13). Decreased levels of let-7c and let-7b-5p are expressed by Neonatal monocytes and CD $4+\mathrm{T}$ cells. Neonatal monocyte participates in antigen presentation and phagocytosis. Neonatal CD $4+\mathrm{T}$ cells produces effector cytokines. It is associated with increased production of IL-10 and IL-13. Decreased production of TNF- $\alpha$ and LPS-induced interleukin IL-6 were seen. It is associated with immune response against infection.

\section{Other miRNAs}

In neonatal monocytes, increased levels of miR-34a-3p, miR424 and miR-582-5p, are found. These miRNAs may be involved in developing the neonatal immune response but not demonstrated in neonatal immune cells and require further study. Significantly decreased levels of miR-96, miR-141 and mi R-1184 are found in neonatal sepsis when compared with uninfected neonates. In neonatal monocytes, after LPS stimulation considerable variations in the levels of various micro-RNA such as miR-454-3p, miR-130a, miR-103 and miR542-3p were demonstrated. $15,20,25$ 


\begin{tabular}{|c|c|c|c|}
\hline $\begin{array}{l}\text { Sl. } \\
\text { No }\end{array}$ & Bacteria & Upregulated & Downregulated \\
\hline 1 & $\begin{array}{l}\text { Gram positive } \\
\text { sepsis }\end{array}$ & $\begin{array}{l}\text { miR-122, miR-135a, miR- } \\
\text { 185, miR-548a-3p, miR- } \\
\text { 549, miR-551b, miR-611, } \\
\text { miR-620, miR-637, miR- } \\
\text { 761, miR-1299 }\end{array}$ & $\begin{array}{l}\text { miR-96, miR-182, miR-210, } \\
\text { miR-222, miR-296-5p, miR-365, } \\
\text { miR-373, miR-582-5p, miR-631, } \\
\text { miR-874, miR-886-3p, miR-886-5p, } \\
\text { miR-940, }\end{array}$ \\
\hline 2 & $\begin{array}{c}\text { Gram negative } \\
\text { sepsis }\end{array}$ & $\begin{array}{l}\text { miR-208a, miR-450a, } \\
\text { miR-486-3p, miR-489, } \\
\text { miR-491-3p, miR-375, } \\
\text { miR-509-3-5p, miR-618, } \\
\text { miR-644, miR-720, miR- } \\
\text { 886-3p, miR-1184. }\end{array}$ & $\begin{array}{c}\text { miR-15a, miR-30a, miR-16, let-7g } \\
\text { miR-17, miR-20a, miR-20b, miR- } \\
\text { 30a, miR-22, miR-26a, miR-28-5p, } \\
\text { miR-29a, miR-30e, miR-33a, miR-93, } \\
\text { miR-101, miR-106a, miR-126, miR- } \\
\text { 130a, miR-141, miR-142-5p, miR- } \\
\text { 143, miR-144, miR-146a, miR-146b- } \\
\text { 5p, miR-151-3p, miR-151-5p, miR- } \\
\text { 181a, miR-193a-3p, miR-199a-3p, } \\
\text { miR-320a, miR-320b, miR-320c, } \\
\text { miR-330-5p, miR-411, miR-425, } \\
\text { miR-558, miR-599, miR-604, miR- } \\
\text { 636, miR-652, miR-768-5p, miR- } \\
\text { 937, miR-1246, miR-1248, miR- } \\
\text { 1284, miR-548l, miR-19a. }\end{array}$ \\
\hline \multicolumn{4}{|c|}{ Table 1. Regulation of Micro RNA in Neonatal Sepsis } \\
\hline
\end{tabular}

\begin{tabular}{|c|c|c|c|c|}
\hline \multirow[b]{2}{*}{$\begin{array}{l}\text { Sl. } \\
\text { no }\end{array}$} & \multirow[b]{2}{*}{$\begin{array}{c}\text { Micro } \\
\text { RNA }\end{array}$} & \multicolumn{2}{|c|}{ Immune response genes } & \multirow{2}{*}{$\begin{array}{c}\text { Other immune associated } \\
\text { target genes }\end{array}$} \\
\hline & & Up regulated & $\begin{array}{l}\text { Down } \\
\text { regulated }\end{array}$ & \\
\hline 1 & $\operatorname{miR}-29 a$ & TBX21, CCR5 & TNFRSF1A & $\begin{array}{c}\text { TRAF3, TRAF4, TRAF5, IL17, } \\
\text { TNFAIP1 }\end{array}$ \\
\hline 2 & $\mathrm{miR}-96$ & IL16 & PTGS2 & $\begin{array}{c}\text { TNFRSF13B, IF130, IL17B, CCR8, } \\
\text { CD4, CD96 }\end{array}$ \\
\hline 3 & $\mathrm{miR}-101$ & IL16, IL13 & PTGS2 & TLR2, CD86, CD163, CXCL6 \\
\hline 4 & $\operatorname{miR}-122$ & $C D 40 L G$ & TNFRSF1B & $\begin{array}{c}\text { IL3, IL18, IL22, CD96, CCL13, } \\
\text { CCL21 }\end{array}$ \\
\hline 5 & $\mathrm{miR}-141$ & IL12B, TBX21 & $I L 1 A$ & CD80, IRF6, CXCL12, IL6R \\
\hline 6 & $\mathrm{miR}-143$ & CTLA4 & PTGS2 & IL36G, BTLA, TLR2 \\
\hline 7 & $\mathrm{miR}-181 \mathrm{a}$ & IL2 & $\begin{array}{l}\text { IL1A, PTGS2, } \\
\text { TLR4 }\end{array}$ & IL1B, IL25, FAS, IRF5, CD69, CD4, \\
\hline 8 & $\operatorname{miR}-182$ & IL13, IL8, FADD & PTGS2 & CCL2, CCL13, CCR9, CD69, IL1F9 \\
\hline 9 & $\mathrm{miR}-185$ & $\begin{array}{l}\text { CCR5, GNLY, } \\
\text { FADD }\end{array}$ & & CD84, BTLA, IL18R1, TNFAIP1 \\
\hline 10 & $\operatorname{miR}-1184$ & IL16 & & $\begin{array}{c}\text { TNF, IL4R, IL21, CCR6, } \\
\text { TNFRSF11A }\end{array}$ \\
\hline
\end{tabular}

\begin{tabular}{|c|c|c|c|c|c|c|c|c|}
\hline Sl. no & Author /year & $\begin{array}{l}\text { Cases and Controls } \\
\text { n = Samples }\end{array}$ & Micro RNA & Regulation & Sensitivity & Specificity & P-value & AUC \\
\hline 1. & Liu et al. 2019 & 102 with NS, 50 without sepsis & $\mathrm{miR}-181 \mathrm{a}$ & Down regulated & $83.3 \%$ & $84 \%$ & $(\mathrm{P}<0.01)$ & 0.893 \\
\hline 2. & $\begin{array}{c}\text { Karam } \\
\text { et al. } 2019\end{array}$ & $\begin{array}{l}55 \text { paediatric sepsis patients and } \\
60 \text { control }\end{array}$ & miR -146a & Down regulated & $86.6 \%$ & $56.6 \%$ & $P=0.0001$ & 0.803 \\
\hline \multirow{3}{*}{3.} & \multirow{3}{*}{ Salim et al. 2020} & \multirow{3}{*}{$\begin{array}{l}50 \text { with NS, } 30 \text { with } \\
\text { SIRS and } 20 \text { healthy neonates }\end{array}$} & miR - 187 & Up regulated & $72 \%$ & $76 \%$ & $P=0.001$ & 0.789 \\
\hline & & & miR - 101 & Up regulated & $84 \%$ & $84 \%$ & $P=0.001$ & 0.908 \\
\hline & & & $\operatorname{miR}-21$ & Up regulated & $64 \%$ & $66 \%$ & $P=0.001$ & 0.711 \\
\hline \multirow{4}{*}{4.} & \multirow{4}{*}{ Dhas et al. 2018} & \multirow{4}{*}{$\begin{array}{l}25 \text { with EOS } \\
\text { and } 25 \text { without sepsis }\end{array}$} & $\operatorname{miR}-132$ & Down regulated & Nil & Nil & $\mathrm{P}<0.01$ & Nil \\
\hline & & & $\operatorname{miR}-146 a$ & Down regulated & Nil & Nil & Nil & Nil \\
\hline & & & $\mathrm{miR}-155$ & Down regulated & Nil & Nil & Nil & Nil \\
\hline & & & $\mathrm{miR}-223$ & Down regulated & Nil & Nil & $\mathrm{P}<0.05$ & Nil \\
\hline \multirow[t]{2}{*}{5.} & \multirow{2}{*}{$\begin{array}{l}\text { Fatmi } \\
\text { et al. }\end{array}$} & \multirow[t]{2}{*}{54 new-borns suspected of sepsis } & \multirow[t]{2}{*}{$\mathrm{miR}-23 \mathrm{~b}$} & Up regulated in EOS & Nil & Nil & $\begin{array}{c}\text { EOS: } \\
\text { preterm }-\mathrm{P}<0.001 \\
\text { full-term }-\mathrm{P}<0.005\end{array}$ & Nil \\
\hline & & & & Down regulated in LOS & Nil & $\mathrm{Nil}$ & $\begin{array}{c}\text { LOS: } \\
\mathrm{P}<0.005\end{array}$ & Nil \\
\hline \multirow[b]{2}{*}{6.} & \multirow[b]{2}{*}{ Chen et al. 2014} & \multirow[b]{2}{*}{48 neonates } & miR-101 / 122 / 185 & Up regulated & Nil & Nil & Nil & Nil \\
\hline & & & $\begin{array}{c}\text { miR- } \\
96 / 182 / 141 / 143 / \\
181 a / 29 a / 1184\end{array}$ & Down regulated & Nil & Nil & Nil & Nil \\
\hline 7. & Yu et al. 2016 & $\begin{array}{c}5 \text { neonates and adults for isolation } \\
\text { of } \\
\text { leukocyte subpopulations } \\
31 \text { neonates and } 19 \text { adults for } \\
\text { isolation of pDC }\end{array}$ & $\begin{array}{c}\text { miR - } \\
\text { let-7b - 5p }\end{array}$ & Down regulated & Nil & Nil & Nil & Nil \\
\hline 8. & Cheng et al. 2018 & 28 cases of neonatal sepsis & $\mathrm{miR}-26 \mathrm{a}$ & Down regulated & Nil & Nil & $\mathrm{P}<0.05$ & Nil \\
\hline 9. & Rateb, et al. 2018 & 80 cases and 20 control & $\begin{array}{l}\mathrm{miR}-16 \\
\mathrm{miR}-34 \mathrm{a}\end{array}$ & $\begin{array}{c}\text { Up regulated } \\
\text { Down regulated }\end{array}$ & $\begin{array}{l}82.5 \% \\
100 \%\end{array}$ & $\begin{array}{c}70 \% \\
78.3 \%\end{array}$ & $\begin{array}{l}(P<0.001) \\
P<0.001)\end{array}$ & $\begin{array}{l}0.802 \\
0.857\end{array}$ \\
\hline 10. & $\begin{array}{l}\text { Ahmed et } \\
\text { al., } 2017\end{array}$ & $\begin{array}{l}24 \text { neonates suggestive of NS, } 22 \\
\text { high risk neonates } 17 \text { healthy } \\
\text { neonates as controls }\end{array}$ & $\operatorname{miR}-146 a$ & Up regulated & $91.7 \%$ & $100 \%$ & 0.037 & 0.99 \\
\hline & & & ble 3. Micro RNA & Diagnostic Markers & & & & \\
\hline
\end{tabular}

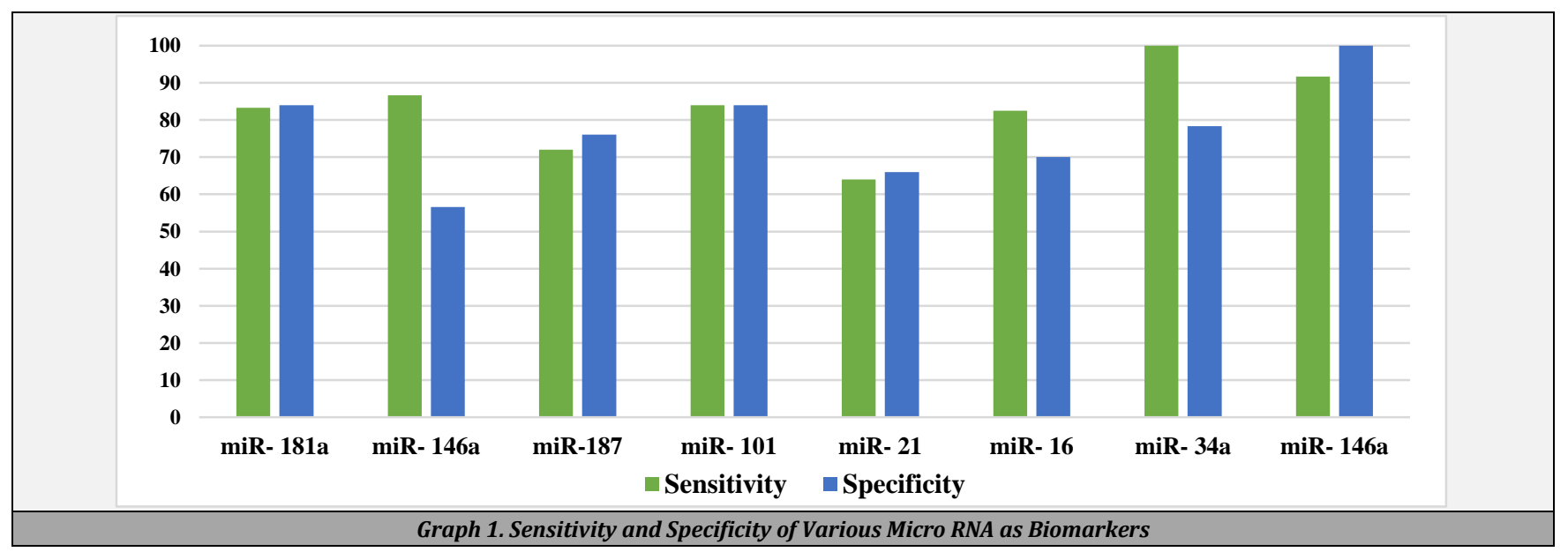


Karam et al. 2019: miR-146a

Salim et al. 2020: miR-187

Salim et al. 2020: miR-101

Salim et al. 2020: miR-21

Hamshary et al. 2018: miR-16

Hamshary et al. 2018: miR-34a

Ahmed et al. 2017: miR- 146a

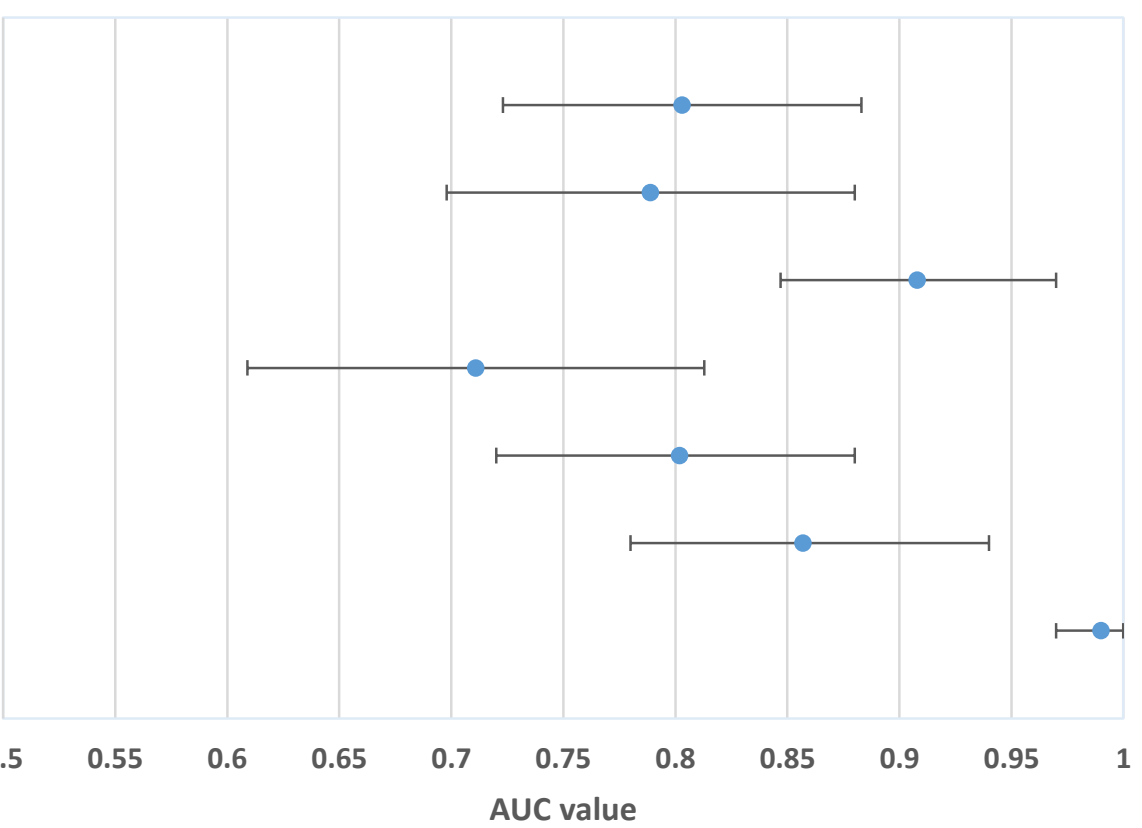

Graph 2. Forest Plot of Various Micro RNA in Diagnosis of Neonatal Sepsis using Area Under Curve Value and $95 \%$ Confidence Interval

\section{CONCLUSIONS}

Difficulty in early diagnosis of neonatal sepsis may be countered by using microRNA as a potential marker. However, there may be variations in the outcomes which must be standardised before including it in routine laboratory testing. Combination of micro RNA along with other biomarkers can be more promising in the diagnosis and prognosis of neonatal sepsis.

Financial or other competing interests: The Financial support was provided by Chettinad Academy of Research and Education.

Disclosure forms provided by the authors are available with the full text of this article at jemds.com.

We thank Prof. Dr. R. Murugesan Director-Research (Chettinad Academy of Research and Education) and Dr. Priyadarshini Shanmugam HOD, Department of Microbiology, (Chettinad Hospital and Research Institute) for valuable suggestions and support.

\section{REFERENCES}

[1] Camacho-Gonzalez A, Spearman PW, Stoll BJ. Neonatal infectious diseases: evaluation of neonatal sepsis. Pediatr Clin North Am 2013;60(2):367-89.

[2] Leal YA, Álvarez-Nemegyei J, Velázquez JR, et al. Risk factors and prognosis for neonatal sepsis in southeastern Mexico: analysis of a four-year historic cohort follow-up. BMC Pregnancy Childbirth 2012;12:48.

[3] Shane AL, Stoll BJ. Neonatal sepsis: progress towards improved outcomes. J Infect 2014;68(Suppl 1):S24-32.

[4] Hedegaard SS, Wisborg K, Hvas AM. Diagnostic utility of biomarkers for neonatal sepsis- a systematic review. Infect Dis (Lond) 2015;47(3):117-24.

[5] Ng S, Strunk T, Jiang P, et al. Precision medicine for neonatal sepsis. Front Mol Biosci 2018;5:70.
[6] Benz F, Roy S, Trautwein C, et al. Circulating microRNAs as biomarkers for sepsis. Int J Mol Sci 2016;17(1):78.

[7] Liu G, Liu W, Guo J. Clinical significance of miR- 181a in patients with neonatal sepsis and its regulatory role in the lipopolysaccharide- induced inflammatory response. Exp Ther Med 2020;19(3):1977-83.

[8] Karam RA, Zidan HE, Karam NA, et al. Diagnostic and prognostic significance of serum miRNA-146-a expression in Egyptian children with sepsis in a pediatric intensive care unit. J Gene Med 2019;21(11):e3128.

[9] Lederhuber H, Baer K, Altiok I, et al. MicroRNA-146: tiny player in neonatal innate immunity?. Neonatology 2011;99(1):51-6.

[10] Salim RF, Sobeih AA, El Kareem HMA. Evaluation of the clinical value of circulating miR-101, miR-187 and miR-21 in neonatal sepsis diagnosis and prognosis. Egyptian J Med Human Gene 2020;21:12.

[11] Zheng G, Xiang W, Pan M, et al. Identification of the association between rs41274221 polymorphism in the seed sequence of microRNA-25 and the risk of neonate sepsis. J Cell Physiol 2019;234(9):15147-55.

[12] Li Y, Ke J, Peng C, et al. microRNA-300/NAMPT regulates inflammatory responses through activation of AMPK/mTOR signaling pathway in neonatal sepsis. Biomed Pharmacother 2018;108:271-9.

[13] Fatmi A, Rebiahi SA, Chabni N, et al. mir-23b: a new molecular marker for neonatal sepsis in haemoculture. 2020. DOI: https://doi.org/10.21203/rs.3.rs-23232/v3

[14] Dhanagovind PT, Kujur PK, Swain RK, et al. miR-142 regulates IL-6 signalling during host immune response to Staphylococcus epidermidis infection in zebrafish. bioRxiv 2020.2 DOI: https://doi.org/10.1101/2020.02.26.960443

[15] Huang HC, Yu HR, Huang LT, et al. miRNA-125b regulates TNF- $\alpha$ production in CD14+ neonatal monocytes via post- 
transcriptional regulation. J Leukoc Biol 2012;92(1):17182.

[16] Cheng Q, Tang L, Wang Y. Regulatory role of miRNA-26a in neonatal sepsis. Exp Ther Med 2018;16(6):4836-42.

[17] Wang X, Wang X, Liu X, et al. miR-15a / 16 are upreuglated in the serum of neonatal sepsis patients and inhibit the LPS-induced inflammatory pathway. Int J Clin Exp Med 2015;8(4):5683-90.

[18] Kingsley SMK, Bhat BV. Role of microRNAs in sepsis. Inflamm Res 2017;66(7):553-69.

[19] El Hamshary AE, El Abd AM, Abd Almonaem ER, et al. The value of circulating miR-16/34 a as potential molecular markers for diagnosis and prognosis of neonatal sepsis. Nature and Science 2018;16(2):1-8.

[20] Yu HR, Huang LH, Li SC. Roles of microRNA in the immature immune system of neonates. Cancer Lett 2018;433:99-106.
[21] Palin AC, Ramachandran V, Acharya S, et al. Human neonatal naive $\mathrm{CD} 4+\mathrm{T}$ cells have enhanced activationdependent signaling regulated by the microRNA miR181a. J Immunol 2013;190(6):2682-91.

[22] Testa U, Pelosi E, Castelli G, et al. miR-146 and miR-155: two key modulators of immune response and tumor development. Noncoding RNA 2017;3(3):22.

[23] Glaesener S, Jaenke C, Habener A, et al. Decreased production of class-switched antibodies in neonatal $\mathrm{B}$ cells is associated with increased expression of miR-181b. PloS One 2018;13(2):e0192230.

[24] Ma F, Xu S, Liu X, et al. The microRNA miR-29 controls innate and adaptive immune responses to intracellular bacterial infection by targeting interferon- $\gamma$. Nat Immunol 2011;12(9):861-9.

[25] Méndez C, Gelgor L, Anderson B. Differential regulation of the Let-7 family of microRNAs in CD4+ T cells alters IL-10 expression. J Immunol 2012;188(12):6238-46. 